\title{
Sulfur Development in the Water-Sediment System of the Algae Accumulation Embay Area in Lake Taihu
}

\author{
Cheng Liu ${ }^{1} * \mathbb{C}^{\mathbb{D}}$, Shiguang Shao ${ }^{2}$, Lei Zhang ${ }^{1}$, Yiheng Du ${ }^{1}$, Kaining Chen ${ }^{1}$, Chengxin Fan ${ }^{1}$ and \\ Yang Yu ${ }^{1}$ \\ 1 State Key Laboratory of Lake Science and Environment, Nanjing Institute of Geography and Limnology, \\ Chinese Academy of Sciences, Nanjing 210008, China \\ 2 Hulun Buir Institute of Water Resources Planning and Designing, Hulun Buir 021000, China \\ * Correspondence: chliu@niglas.ac.cn
}

Received: 6 July 2019; Accepted: 29 August 2019; Published: 31 August 2019

check for updates

\begin{abstract}
Sulfur development in water-sediment systems is closely related to eutrophication and harmful algae blooms (HABs). However, the development of sulfur in water-sediment systems during heavy algae accumulation still remains unclear, especially in hyper-eutrophic shallow lakes. In this study, a quarterly field investigation was carried out for a year in the algae accumulated embay area of Lake Taihu, accompanied by a short-term laboratory experiment on algae accumulation. The results show that hydrogen sulfide and methanethiol dominated the volatile sulfur compounds (VSCs) in the water during non-accumulation seasons, whereas the concentrations of dimethyl sulfides increased during heavy algae accumulation, both in the field and the laboratory. An increase in the acid volatile sulfide (AVS) in the surface sediments was also discovered together with the increase in dimethyl sulfides. The depletion of oxygen in the overlying water and sediment-water interface during the heavy algae accumulation and decomposition was found to be closely related to both the increase in VSCs in the overlying water and increase in AVS in the sediment. The increased concentrations of these reductive sulfocompounds might aggravate the eutrophication and HABs and should be given more consideration in future eutrophication control plans for lakes.
\end{abstract}

Keywords: sulfur; water-sediment system; algae accumulation; volatile sulfur compounds; acid volatile sulfide

\section{Introduction}

Eutrophication affects many lakes and coastal waters around the world. This is due to the excessive accumulation of nitrogen $(\mathrm{N})$ and phosphorus $(\mathrm{P})$ in the water, leading to the excessive multiplication of phytoplankton and harmful algae blooms (HABs) [1,2]. HABs can lead to water sources becoming hypoxic [3], and subsequently result in threats to aquatic plants and animals [4,5]. As eutrophication and HABs increase, populations of submerged plants usually decrease simultaneously $[5,6]$. The competition for nutrients and space [7], and the attenuation of light [8], triggered by HABs, are believed to be responsible for the declining abundance of submerged plants. This results in a regime shift of a lake from macrophyte-dominated clear water to phytoplankton-dominated turbid water $[9,10]$. This shift may alter the migration of several associated elements, including nitrogen $(\mathrm{N})$, phosphorus $(\mathrm{P})$, sulfur (S), and iron (Fe), throughout the water system [11-13]. Among these elements, $\mathrm{S}$ is important to the water-sediment system because of its influence on the migration of eutrophication associated P $[13,14]$ and its negative influence on the growth of submerged plants [15,16].

In coastal waters, high levels of sulfate accelerate the release of $P$ from the sediments, both under oxic and anoxic conditions [17]. Therefore, many saline waters tend to be $\mathrm{P}$ sufficient for phytoplankton [18], while many freshwaters tend to be P limited [19]. In freshwaters, the supply 
of $\mathrm{P}$ to phytoplankton increases when the release of $\mathrm{P}$ from the sediments increases under anoxic conditions [20,21]; this usually occurs during algal blooms [22-24]. The formation of sulfides facilitates the formation of ferrous sulfide ( $\mathrm{FeS}$ ) and the release of $\mathrm{P}$ from the sediments [14], aggravating eutrophication and HABs in the water. This process usually takes place in freshwater sediments because of the low sulfate concentration of freshwater [14,25]. However, in the overlying water, another problem is the formation of volatile sulfur compounds (VSCs) during HABs. Various VSCs, including hydrogen sulfide $\left(\mathrm{H}_{2} \mathrm{~S}\right)$, methanethiol (MTL), dimethyl sulfide (DMS), dimethyl disulfide (DMDS), and dimethyl trisulfide (DMTS), have been detected during HABs [26-28]. MTL, DMS, DMDS, and DMTS are also known as volatile organic sulfur compounds (VOSCs). The high concentration of VSCs causes freshwater sites to become more odorous [29,30]. In 2007, a crisis occurred in Wuxi City, China, resulting from the accumulation of algae in Lake Taihu, the city's drinking water source, in which the tap water turned black and became odorous [31,32]. High levels of VSCs were found to be responsible for the crisis [31,32]. VSCs are difficult to remove from drinking water sources through conventional techniques due to the high cost and the residual of the processes required [33]. Therefore, it is imperative to understand the origin and formation of VSCs in drinking water sources such as lakes and reservoirs.

Although the formation and migration of sulfides and VSCs have been noted and studied worldwide [28,34], the development of these compounds in the water and sediment systems still remains unclear, especially in large and shallow eutrophic lakes with serious HABs. The overlying water in shallow lakes mostly maintains oxic conditions because of wind and benthic disturbance [35]. However, during serious HAB seasons, the high accumulation of algae in the water can lead to the depletion of oxygen in the water and sediments [23,24]. These anoxic conditions lead to a reduction in sulfates and decomposition of algae [36]. The concentrations of sulfides and VSCs might increase accordingly [25,27], particularly in algae accumulation areas. Nevertheless, some details still remain unclear: 1) The detailed development of these compounds in water-sediment systems during the algal bloom season with a high algae accumulation in shallow and eutrophic lakes; and 2) the detailed mechanisms for the formation and development of these compounds. In this study, a year-long investigation was carried out in an algae accumulation bay area in the hyper-eutrophic Lake Taihu to explore the development of reductive sulfocompounds related to eutrophication and HABs. An algae accumulation experiment was also carried out in the laboratory to further investigate the mechanisms for the development of sulfur in water-sediment systems. Information acquired in this study could be helpful for revealing the sulfur transport and transformation in algae accumulation areas in similar eutrophic shallow lakes and for the management of eutrophication.

\section{Materials and Methods}

\subsection{Field Investigation Area and Sampling}

Lake Taihu $\left(30^{\circ} 55^{\prime} 40^{\prime \prime}-31^{\circ} 32^{\prime} 58^{\prime \prime} \mathrm{N}\right.$ and $\left.119^{\circ} 52^{\prime} 32^{\prime \prime}-120^{\circ} 36^{\prime} 10^{\prime \prime} \mathrm{E}\right)$ is the third largest fresh water lake along the middle and lower reaches of Yangtze River, with an area of $2338 \mathrm{~km}^{2}$ and a mean depth of $1.9 \mathrm{~m}$ [37]. It is a typical large and shallow eutrophic lake with an algal bloom area that can engulf $75 \%$ of the lake during blooming seasons [38]. The northwestern area is the primary area for algae accumulation because of the serious pollution from the inflowing rivers and surrounding cities and the influence of the East Asian monsoon [38,39]. Lake Taihu is a drinking water source for the surrounding cities, including Wuxi and Suzhou. Every year, efforts are made to aid the recovery of the hyper-eutrophic lake. However, serious HABs and associated disasters such as the black water aggregation $[25,40]$ are observed every year. During blooming seasons, the whole lake is odorous because of the presence of reductive sulfocompounds [41]. To investigate the development of sulfur in the water-sediment system of the algae accumulation area, a year-long field investigation was carried out quarterly in 2014 in Moon Bay, one of the most prominent algae accumulation areas in Lake Taihu. 
Four algae accumulation sites in the littoral area and one site in an open water area (Figure 1) were investigated in January (winter), April (spring), July (summer), and October (autumn) in 2014. The investigation in July (serious blooming season) was carried out after at least 10 days of continuous southeast monsoon conditions to make sure that the typical algae accumulation period was investigated. The accumulation of algae usually followed a descending order from S1 to S5 during the blooming season due to the shape of the bay and the summer monsoon (Figure 1). In each investigation period, three sediment cores were collected from each sampling site using a gravity corer (110 mm diameter $\times 500 \mathrm{~mm}$ length; Rigo Co., Ltd., Saitama, Japan). All the sediment cores were transported to the bank immediately for analyses of dissolved oxygen (DO) profiles. A micro-profiling system (Unisense, Aarhus, Denmark) was used for the DO profile analysis. Details of the DO profiles analysis procedure are described further in Section 2.4. Three water samples were collected from each site using $100 \mathrm{~mL}$ of polyethylene bottles, without headspace. The water samples were preserved at $4{ }^{\circ} \mathrm{C}$ in a portable refrigerator and transported to the laboratory for the VSC analysis. The sediment cores were also transported to the laboratory without disturbance for further analysis.

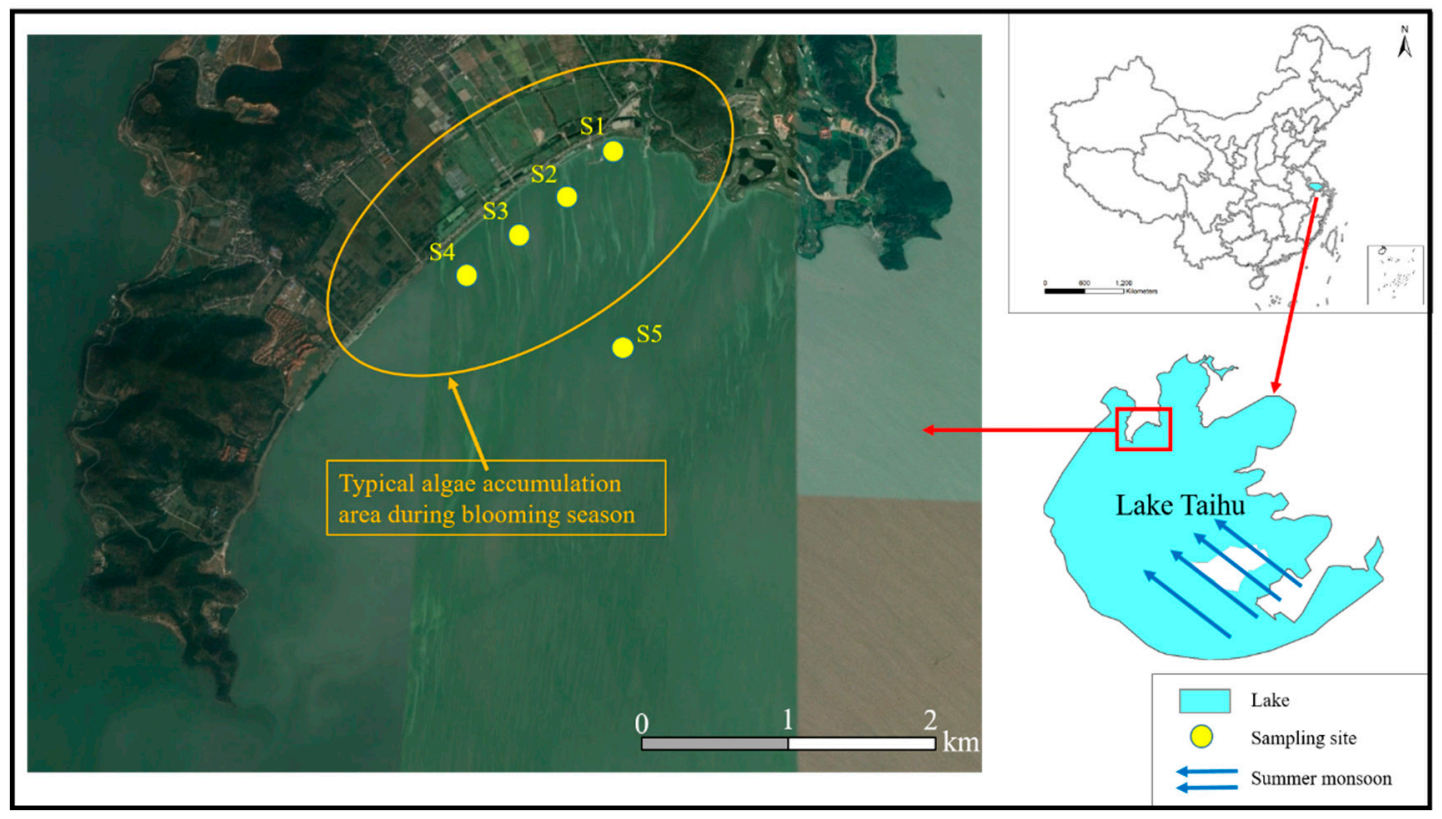

Figure 1. Location map of the sampling sites.

\subsection{Algae Accumulation Experiment in the Laboratory}

A simulated algae accumulation experiment was carried out in the laboratory to determine the development of organic and inorganic sulfur in both the water and sediment. In July 2014, six sediment cores with a depth of $20 \mathrm{~cm}$ were collected from site S1 (Figure 1) and transported to six simulated column apparatuses with $1.8 \mathrm{~m}$ of overlying water, which was approximately the mean water depth of Lake Taihu [37]. The columns were made of transparent polymethyl methacrylate. The overlying water was also collected from the sampling site and filtered through $0.45 \mu \mathrm{m}$ membranes to remove algae particles from the water. Three columns were taken for the algae accumulation treatment with the addition of approximately $47.5 \mathrm{~g}$ of drained algae to each column (approximately $5000 \mathrm{~g} \mathrm{~m}^{-2}$, which was close to the highest algae accumulation amount in bay areas in Lake Taihu [42]). More than 99\% of the algae in Lake Taihu were cyanobacteria [35]. Another three columns contained no algae, and these were used as control treatments. The algae accumulation experiment was carried out for seven days, when most of the accumulated algae died because of the high accumulation amount [43]. The experiment was carried out in summer room temperature conditions $\left(35 \pm 3^{\circ} \mathrm{C}\right)$. The fluorescent lamps were used during the daytime. VSCs, DO, and chlorophyll a (Chla) in the overlying water 
were measured daily. The acid volatile sulfide (AVS) in the sediment was analyzed at the end of the experiment.

\subsection{Analysis of Sulfur in the Water and Sediment}

All the water and sediment samples were preserved at $4{ }^{\circ} \mathrm{C}$ after sampling and analyzed within $24 \mathrm{~h}$. The analysis of VSCs in the water samples, including $\mathrm{H}_{2} \mathrm{~S}$, MTL, DMS, DMDS, and DMTS, was carried out using a headspace solid-phase micro-extraction (HS-SPME) coupled with gas chromatography [22, 27]. A $20 \mathrm{ml}$ sample was used for the extraction of the VSCs. The sample was extracted at $65{ }^{\circ} \mathrm{C}$ with agitation at $150 \mathrm{r} / \mathrm{min}$ for $30 \mathrm{~min}$. A 50/30 $\mu \mathrm{m} \mathrm{DVB/carboxen-PDMS} \mathrm{fiber} \mathrm{(Supelo,} \mathrm{No.57348-U,}$ Sigma-Aldrich, St. Louis, MO, USA) was used for the extraction. After that, an Agilent 7890A gas chromatography system (Agilent Technologies, Santa Clara, CA, USA) equipped with a flame photometric detector (FPD) was used for the analysis of VSCs. The extraction of VSCs was done using a GAS-PRO capillary PLOT column $(60 \mathrm{~m} \times 0.32 \mathrm{~mm}$; Agilent Technologies, Santa Clara, CA, USA). The parameters of the GC-FPD affecting the analysis are mentioned in the literature [22,27]. Standard solutions for the VSCs were acquired from Sigma-Aldrich. The detection limit for the VSCs was $2 \mathrm{ng} / \mathrm{L}$. The VSC recovery rates ranged from $90 \%-110 \%$.

The sediment cores were sectioned in an anaerobic operating box at intervals of $1 \mathrm{~cm}, 2 \mathrm{~cm}, 5 \mathrm{~cm}$, $10 \mathrm{~cm}$, and $15 \mathrm{~cm}$. The subsamples were preserved at $4{ }^{\circ} \mathrm{C}$ under anoxic conditions and analyzed within $4 \mathrm{~h}$ after the section. The AVS in the sediment was extracted using cold-diffusion methods modified from Allen et al. [44]. Approximately $5 \mathrm{~g}$ of fresh, sectioned sediment sample was extracted using $15 \mathrm{~mL}$ of $6 \mathrm{~mol} \mathrm{~L}^{-1}$ hydrochloric acid $(\mathrm{HCl})$. The $\mathrm{H}_{2} \mathrm{~S}$ was trapped with an alkaline zinc solution in an oxygen-free environment. The sulfide in the extract was analyzed using the methylene blue method [45]. All reagents used during the extraction and analysis were bubbled with oxygen-free nitrogen.

\subsection{Chemical Analysis}

The profiles of DO across the sediment-water interface (SWI) were analyzed immediately after sampling. The distribution of DO across the SWI was measured at a resolution of $0.1 \mathrm{~mm}$ using a micro-profiling system (Unisense, Aarhus, Denmark). The oxygen uptake rate (OUR) of the sediment was calculated based on the DO profiles according to Rasmussen and Jorgensen [46]:

$$
R=D_{s} \frac{d^{2} C}{d^{2} z}
$$

where $R$ is the OUR $\left(\mathrm{mg} \mathrm{m}^{-3} \mathrm{~s}^{-1}\right), C$ is the concentration of oxygen $\left(\mathrm{mg} \mathrm{L}^{-1}\right), z$ stands for the depth of the sediment, and $D_{s}$ is the oxygen diffusion coefficient $\left(\mathrm{m}^{2} \mathrm{~s}^{-1}\right)$. $D_{s}$ is calculated according to the theoretical diffusion coefficient of oxygen $\left(D_{0}\right)$ and the sediment porosity $(\varphi)$ [47]:

$$
D_{s}=\frac{D_{0}}{1-2 \ln \varphi}
$$

After the sediment cores were sectioned in the laboratory, about $30 \mathrm{~g}$ of the fresh subsamples were dried at $105^{\circ} \mathrm{C}$ to a constant weight to measure the water content. The porosity of the sediment was calculated according to the water content [48]. The remaining subsamples were freeze-dried in a vacuum freeze drier (Biosafer-10A, Biosafer, Nanjing, China), ground in an agate mortar, and sieved through a 100 mesh screen $(0.150 \mathrm{~mm})$ for further chemical analysis. The concentrations of total nitrogen $(\mathrm{TN})$ in the sectioned sediment samples were determined through extraction in alkaline potassium persulfate [49]. The concentrations of total phosphorus (TP) in the sectioned sediment samples were determined through extraction in $3.5 \mathrm{~mol} \mathrm{~L}^{-1} \mathrm{HCl}$ for $16 \mathrm{~h}$ after ignition at $550{ }^{\circ} \mathrm{C}$ for $3 \mathrm{~h}$ [50]. The loss on ignition (LOI) of the sediment, representing the organic matter in the sediment, was determined after ignition at $550^{\circ} \mathrm{C}$ for $5 \mathrm{~h}$ [51]. 


\subsection{Statistical Analysis}

All data figures were plotted using the Origin 2015 software (OriginLab, Northampton, MA, USA). The analysis of covariance (ANCOVA) was carried out to identify: 1) The differences in TN and TP concentrations, and LOI, at different sediment depths at different sites across the seasons; 2) the differences in AVS concentrations in the surface sediment at different sites across the seasons; 3) the differences in VSC concentrations in the water at different sites across the seasons; and 4) the differences in oxygen penetration depth (OPD) across the SWI at different sites across the seasons. The equal slopes and parametric assumptions of ANCOVA were generally met during the analysis. The mean values for the variables were used for the analysis. The details of the ANCOVA were shown in Table S1 in the supplementary material. Pearson's correlation tests were also carried out to identify the correlations between various variables in the water and the sediment, including VSCs in the water and the AVS, TN, and TP concentrations, and LOI in the sediment. The post-hoc test was carried out to identify the differences of the TN, TP, and LOI profiles between the sites. The significance levels were reported at $p<0.05$ and $p<0.01$. The principal component analysis was carried out to analyze the correlations between different characteristics of the water and sediments. These analyses were carried out in the SPSS 19.0 (IBM, New York, NY, USA).

\section{Results and Discussion}

\subsection{Sediment Properties and Variations}

The concentrations of TN, TP, and LOI decreased as the sediment depth increased (Table S2 in the supplementary material); this result agrees with those of previous studies [52]. There was no significant difference in the TN profiles for all the sites across the seasons (analysis A1 in Table S1, $p=0.525,0.650,0.994,0.612$, and 0.240 for S1, S2, S3, S4, and S5, respectively). S1 showed a significant difference in TP $(p=0.010)$, but the remaining four sites showed no difference (analysis A1 in Table S1, $p=0.668,0.769,0.991$, and 0.455 for S2, S3, S4, and S5, respectively). LOI was significantly different at S2 ( $p=0.047$ ), but not at the remaining four sites (analysis A1 in Table S1, $p=0.475,0.076,0.549$, and 0.551 for S1, S3, S4, and S5, respectively) for the sediment cores collected over the course of the year. However, the concentrations of TN and TP, and LOI, in the surface sediments showed an obvious variation over the investigation period, especially during the highest blooming seasons (July and October). The concentrations of TN, TP, and LOI in the top $1 \mathrm{~cm}$ layer of the surface sediments in July and October were noticeably higher than those in January and April (Table S2). This phenomenon was most obvious at site S1. Significant differences in the TN and TP concentrations $(p=0.049$ and $p=0.002$, respectively), and LOI $(p=0.013)$, were discovered between different sites across the seasons. The post-hoc test results also showed that the profiles of TN $(p<0.05)$, TP $(p<0.05)$, and LOI $(p<0.05)$ in S1 were significantly different from those of the other sites. The concentrations of TN, TP, and LOI in the top $1 \mathrm{~cm}$ layer of the surface sediments at $\mathrm{S} 1$ were in the range of $1479.6-3573.2 \mathrm{mg} \mathrm{kg}^{-1}$, 435.9-654.9 $\mathrm{mg} \mathrm{kg}^{-1}$, and 4.13-6.93\% (Table S2), with the highest values 2.4, 1.5, and 1.7 times higher than the lowest values. In addition, the concentrations of TN and TP, and the LOI, in the top $1 \mathrm{~cm}$ of core S1 were higher than those from the other sites. Site S1 usually had more algae accumulation amount than other sites during the algae blooming season. The long-term accumulation of algae in the bay led to the deposition of algae-related suspended particulate matter. The N, P, and organic matter were concentrated in this particulate matter [53], which might result in high levels of the N, P, and organic matter in the surficial sediment. This showed that there was an obvious decrease in the concentrations of TN and TP, and LOI levels, as the depth of the sediment increased (Table S2).

\subsection{Oxygen Profiles and Uptake Rates Across the SWI}

The OPD was higher during winter (January) and spring (April) (Figure 2) with a lower temperature and less blooming algae. The OPDs of all the sites were similar during the investigation (analysis A2 in Table S1, $p=0.432$ ), and site S5 had the highest OPD during the investigation. In January, the OPDs of 
the study sites were $>2 \mathrm{~mm}$, with the highest OPD of $5 \mathrm{~mm}$ observed in S5. The size of OPDs at each site was as follows: S5 $>$ S4 $>$ S2 $>$ S3 $>$ S1. The OPDs decreased gradually from January to July. In July, the sediment cores of the sites S1, S2, and S3 were in totally anoxic conditions. The DO concentrations at sites S1, S2, and S3 were nearly $0 \mathrm{mg} \mathrm{L}^{-1}$ across the SWI. The DO concentration at site S4 was less than $2 \mathrm{mg} \mathrm{L}^{-1}$ and decreased sharply from the overlying water to the sediment, with the OPD being less than $2 \mathrm{~mm}$. In October, the DO concentrations at sites S1, S2, S3, and S4 increased, while the OPDs were still low $(<2 \mathrm{~mm})$. The OPD at S1 was still $0 \mathrm{~mm}$ in October. The OPDs at site S5 were higher in July and October, but were still $<2 \mathrm{~mm}$. A significant difference $(p=0.018)$ in the OPDs between the seasons was discovered.

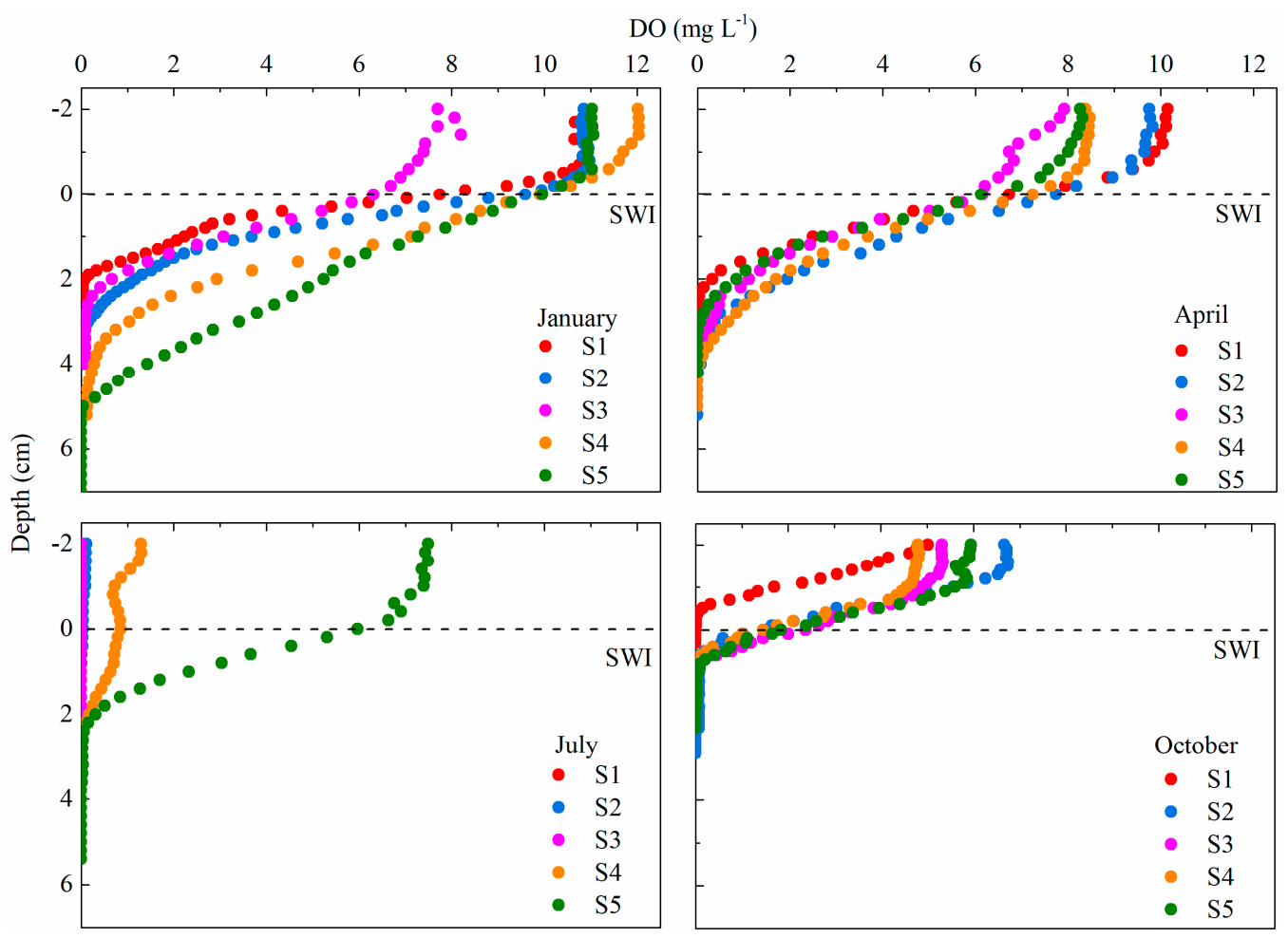

Figure 2. Dissolved oxygen (DO) profiles distributed across the sediment-water interface (SWI) during the field investigation period.

The OURs were calculated according to the DO profiles. From January to October, the OURs at the study sites generally increased (Figure 3). The OURs for sites S1, S2, S3, and S4 were at or nearly $0 \mathrm{mg} \mathrm{m}^{-3} \mathrm{~s}^{-1}$ in July, because there was nearly no oxygen across the SWI (Figure 2). The increased OURs from January to October indicated that there was an increased demand for, and depletion of, oxygen across the SWI, with the increased temperature and algal blooming. During the highest algal blooming season (July and October), the excessive accumulation of algae led to the death and deposition of algal particles on the surface sediments [43], consuming oxygen quickly and leading to the depletion of oxygen across the SWI [23,54]. Therefore, the OURs in October were much higher than those in January and April (Figure 3). The increased OURs and the associated depletion of oxygen across the SWI might influence the development of sulfur and other elements $[25,40]$. 


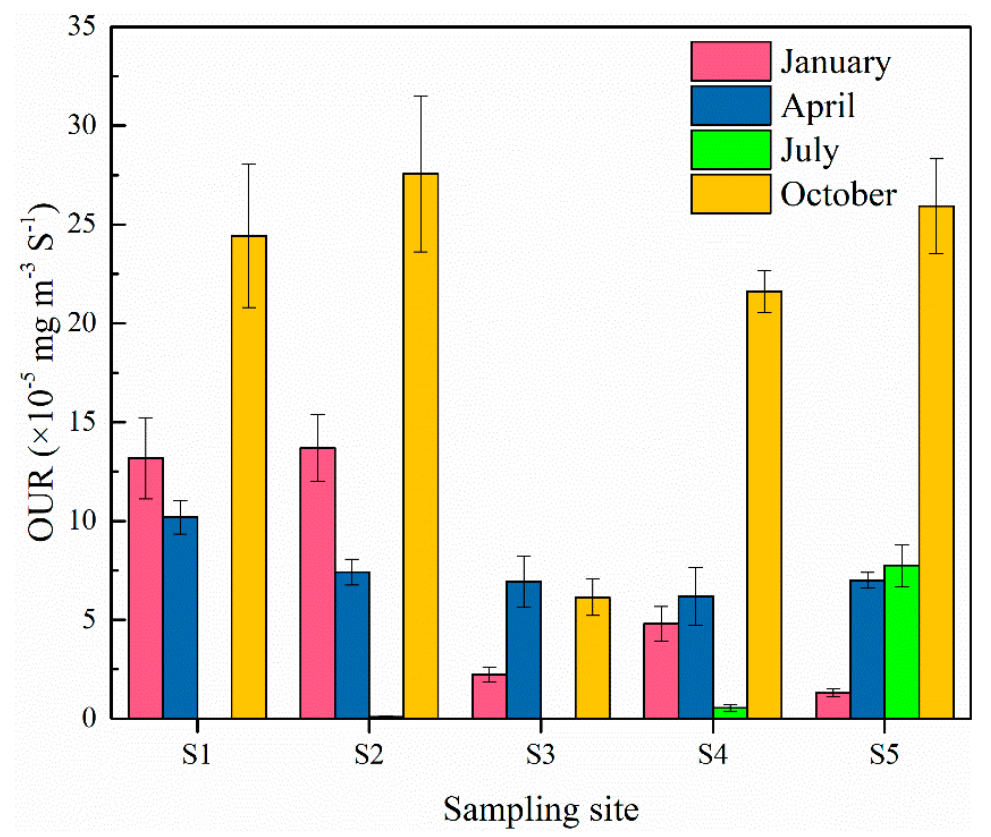

Figure 3. Oxygen uptake rate (OUR) of the sediment during the field investigation period. Error bars indicate the standard deviation, $\mathrm{n}=3$.

\subsection{Profiles of AVS in the Sediment}

The high content of the organic matter in the sediment core (Section 3.1) and the depletion of oxygen with the increase of the sediment depth (Section 3.2) led to the reductive condition in the deeper sediment. The concentrations of AVS increased with the sediment depth (Figure 4) because of the intensification of reduction conditions in the deeper sediment [55]. Significant differences in the AVS of the surface sediments was discovered between the different seasons (analysis A3 in Table S1, $p=0.020)$ and different sites $(p=0.025)$. The concentrations of AVS in the top $2 \mathrm{~cm}$ layer of the surface sediments were lower during January and April, which may have been because of the higher OPD and oxic conditions in the surface sediments during these two seasons [56]. However, a noticeable increase in AVS concentrations was observed in the surface sediments in July. Previous studies showed that the sulfate reduction and sulfide formation begins to occur when the oxygen concentration decreases below $0.05 \mathrm{mg} \mathrm{L}^{-1}$ [56]. In addition, the high sulfate reduction in the surface sediments due to anoxic conditions and high microbial activity intensified the formation of sulfides [57]. Therefore, the concentrations of AVS in the surface sediments increased in July when DO concentrations were extremely low and the microbial activity was higher than that in other seasons [58]. The increase was prominent at sites $\mathrm{S} 1, \mathrm{~S} 2$, and $\mathrm{S} 3$ because the oxygen concentrations were nearly $0 \mathrm{mg} \mathrm{L}^{-1}$ across the SWI at these sites (Figure 2). The AVS concentrations in the top $1 \mathrm{~cm}$ layer of the surface sediments decreased again in October because of the increase in OPD. The increase in sulfides during the algal blooming seasons could cause a release of sulfides to the overlying water and increase the formation of atramentous $\mathrm{FeS}$ and $\mathrm{MnS}$, resulting in the discoloration of water [40,59]. This phenomenon has been observed in many algae accumulation areas in Lake Taihu and other waters [31,60]. 


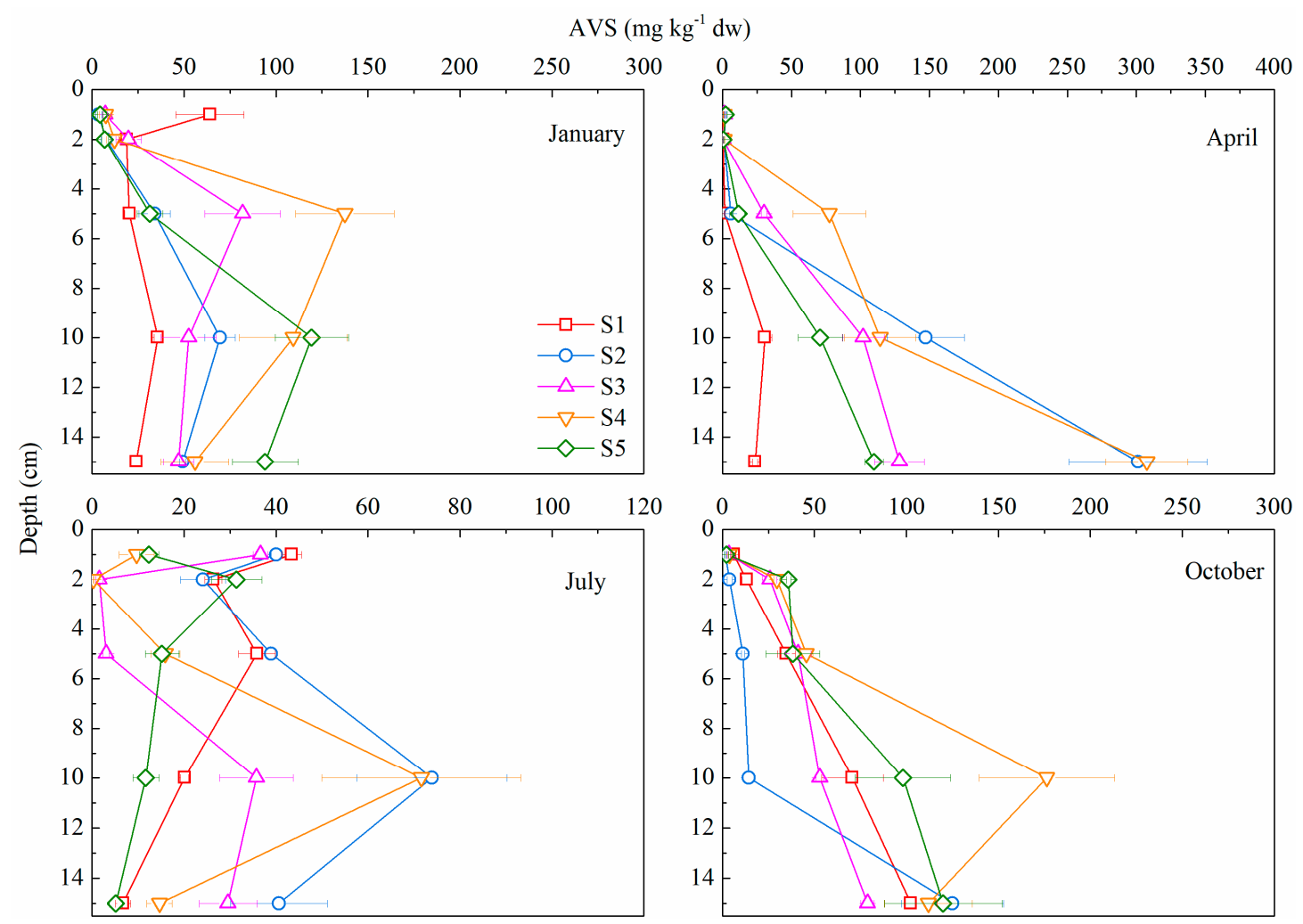

Figure 4. Acid volatile sulfide (AVS) profiles in the sediment during the field investigation period. Error bars indicate the standard deviation, $\mathrm{n}=3$.

\subsection{Volatile Sulfur Compounds in the Water}

The concentrations of MTL, DMS, and DMDS in January, April, and October were under the odor-threshold concentrations (OTCs, 2.1, 1.0, and $4.0 \mu \mathrm{g} \mathrm{L}{ }^{-1}$ for MTL, DMS, and DMDS, respectively, Figure 5) [61]. However, the concentrations of DMTS across the sites during these three seasons were higher than the OTC because of the low OTC of DMTS $\left(0.01 \mu \mathrm{g} \mathrm{L}^{-1}\right)$ [61]. The concentrations of MTL and $\mathrm{H}_{2} \mathrm{~S}$ were noticeably higher than those of other VSCs during January, April, and October. The concentrations of all VSCs were much higher in July (summer) than those in the other three seasons (Figure 5). The concentrations of VOSCs in July were higher than those of OTCs, especially at sites S1, S2, and S3. The DMS concentrations at S1 and S2 were 20 times those of OTCs. Unlike the dominant forms of VSCs, such as MTL and $\mathrm{H}_{2} \mathrm{~S}$, in other seasons, the dominant VSCs in July were DMS and $\mathrm{H}_{2} \mathrm{~S}$. The differences in the DMDS $(p=0.040)$, DMTS $(p=0.036)$, and $\mathrm{H}_{2} \mathrm{~S}(p=0.040)$ concentrations were significant at different sites across the seasons, while those for MTL $(p=0.052)$ and DMS $(p=0.057)$ were not significant (analysis A4 in Table S1). A decreasing trend for VSCs was observed in July at sites S1 to S5, indicating a dispersal of VSCs from the littoral algae accumulation area to the open water. This phenomenon suggests that a close relationship exists between the algae accumulation and the VSCs present. 


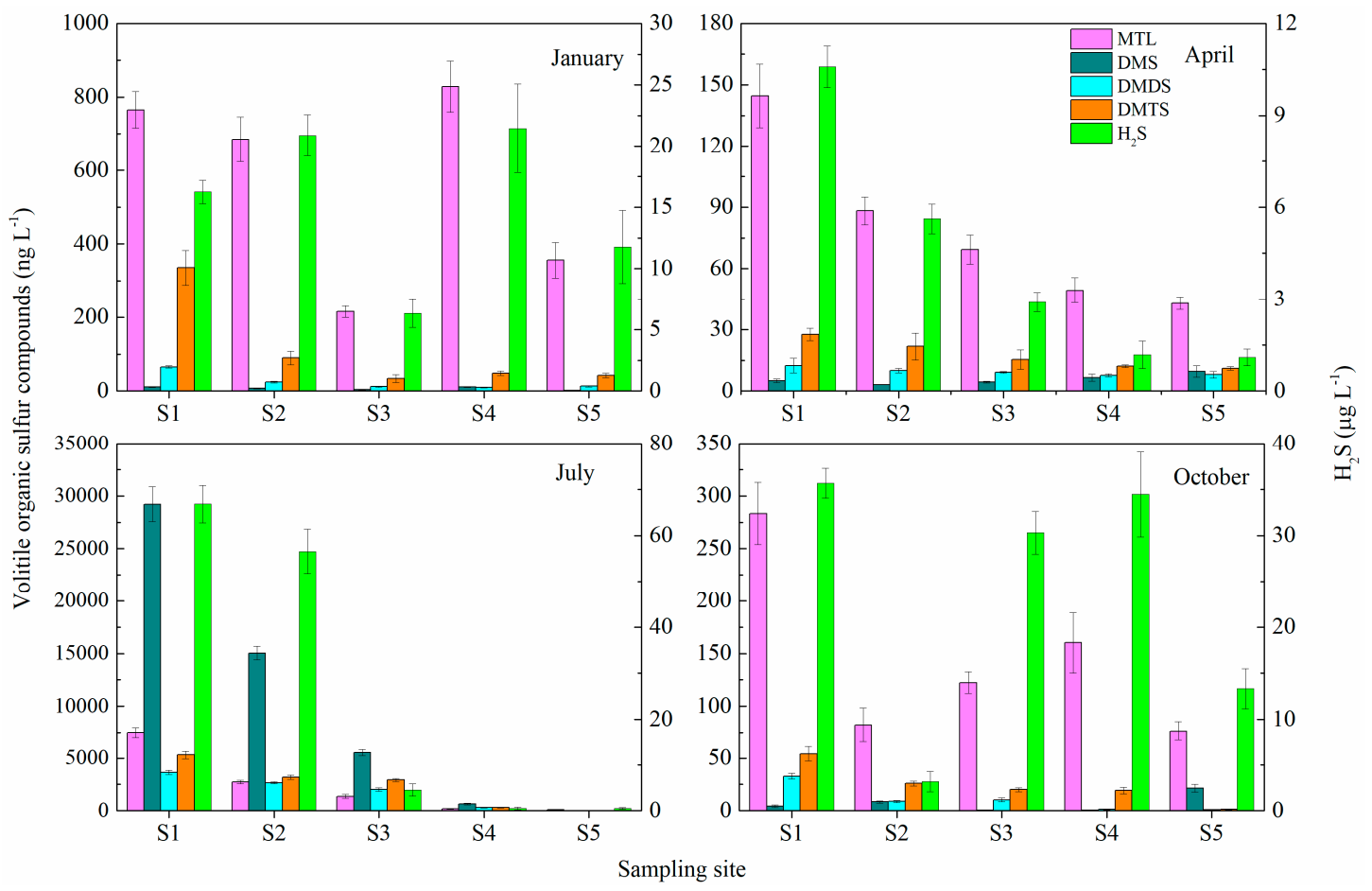

Figure 5. Concentrations of volatile sulfur compounds in water during the field investigation period. Error bars indicate the standard deviation, $\mathrm{n}=3$.

\subsection{Sulfur Development During the Algae Accumulation Experiment}

The algae accumulation experiment showed that VSCs in the water increased exponentially after three days (Figure 6a), when the concentrations of Chla decreased accordingly (Figure 6c). This might be a result of the death of the accumulated algae. In contrast, VSCs in the control treatment remained stable (Figure $6 \mathrm{~b}$ ). The concentrations of DO in the algae accumulated columns decreased from $>7 \mathrm{mg} \mathrm{L}^{-1}$ to $<0.1 \mathrm{mg} \mathrm{L}^{-1}$ after two days of accumulation and decomposition of the algae (Figure 6e), which supported findings from previous studies [22,40]. These results indicated that the death and decomposition of algae takes place during large algae accumulations. A previous study by Shang et al. [43] also found that the algae died quickly after two days of accumulation. The decomposition of algal particles led to the sharp depletion of oxygen in the water [22,40], which in turn accelerated the further decomposition of the algal particles. Similar to the forms of VSCs in the field algae accumulation area in July, the MTL was not noticeably higher than other VOSCs in other seasons. Under the anoxic conditions during the algae decomposition, MTL and $\mathrm{H}_{2} \mathrm{~S}$ were produced in large quantities (Figure $6 \mathrm{~b}$ ) through the decomposition of sulfur-containing amino acids [62,63]. The other forms of VOSCs, including DMS, DMDS, and DMTS, were formed subsequently [64]. The DMS, DMDS, and DMTS could be oxidized to dimethyl sulfoxide, dimethyl sulfone, and other substances in oxic environments. While the algae particles degraded during the algae accumulation, the water column was mostly under anoxic conditions (under $0.1 \mathrm{mg} \mathrm{L}^{-1}$ ), leading to the high concentrations of DMS, DMDS, and DMTS.

The algae accumulation and decomposition led not only to an increase in VSCs in the overlying water, but to an increase in AVS in the surface sediments (Figure 6d). At the end of the algae accumulation experiment, the concentration of AVS in the top $1 \mathrm{~cm}$ layer of the surface sediments in the algae accumulation treatment columns was $76.90 \mathrm{mg} \mathrm{kg}^{-1} \mathrm{dw}$, which is much higher than that in the control treatment $\left(35.08 \mathrm{mg} \mathrm{kg}^{-1} \mathrm{dw}\right)(p=0.043)$. This was similar to the development of AVS in the surface sediments in July during the field investigations (Section 3.3), indicating that the formation of reductive sulfur occurred in both the water and sediment during the algae accumulation. The depletion of oxygen during the accumulation and decomposition of the algae led to the formation of reductive 
sulfocompounds in the water and the reduction of sulfates in the sediment [25]. The reduction of sulfates in the sediment during the algae accumulation led to the increase in AVS in the surface sediments (Figure 6d).
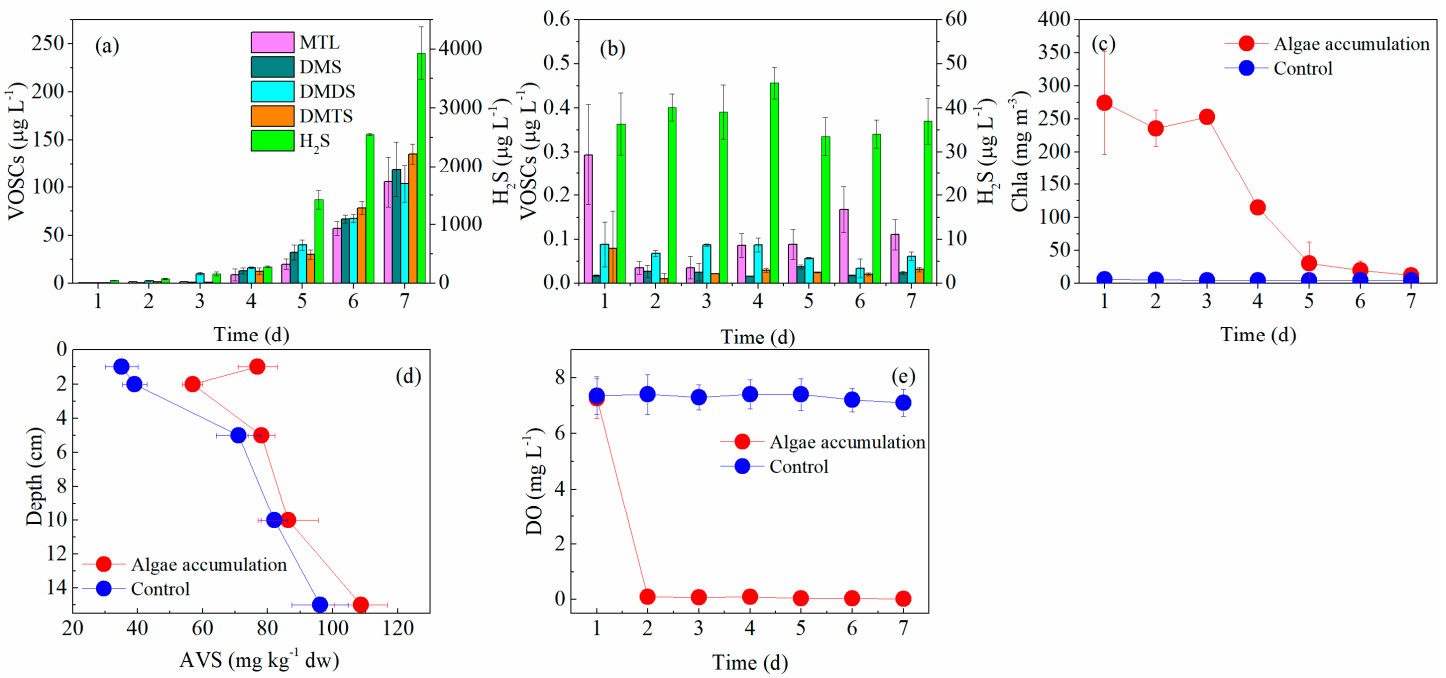

Figure 6. Development of the characteristics of the water-sediment system during the algae accumulation experiment: (a) Volatile sulfur compounds in the water during the algae accumulation; (b) volatile sulfur compounds in the control treatment; (c) the concentrations of chlorophyll $a(\mathrm{Chl} a)$ in the water during the algae accumulation experiment; (d) profiles of acid volatile sulfide (AVS) at the end of the algae accumulation experiment; and (e) dissolved oxygen (DO) in the water during the algae accumulation experiment. Error bars indicate the standard deviation, $n=3$.

\subsection{Mechanisms for the Formation and Development of Reductive Sulfocompounds in the Water-Sediment System}

VSCs in the water were formed from dimethylsulfoniopropionate (DMSP) [26,28], which originates from sulfur-containing amino acids [27]. Previous studies revealed that the heightened concentrations of VSCs observed in Lake Taihu are driven by high levels of sulfur-containing amino acids in the algae itself and an increased abundance of the algae during the accumulation season [65]. MTL and $\mathrm{H}_{2} \mathrm{~S}$ were formed primarily with the decomposition of sulfur-containing amino acids in the algae $[62,63]$. Consequently, dimethyl sulfides (DMS, DMDS, and DMTS) were formed through the methylation and oxidation of MTL [28,33], while the DMS, DMDS, and DMTS were further oxidized to dimethyl sulfoxide in oxic environments [28,33]. Therefore, the concentrations of MTL and $\mathrm{H}_{2} \mathrm{~S}$ were higher than those of other VSCs in January, April, and October. The generally oxic environment in the water during these three months led to the oxidation of DMS, DMDS, and DMTS and thereby hindered the accumulation of these VSCs in the water. In July, the accumulation and decomposition of the bloomed algae led to an increase in DMS, DMDS, and DMTS. The accumulation of a large amount of algae in the embay area led to the death and decomposition of the algae [43], accompanied with oxygen concentrations decreasing to nearly $0 \mathrm{mg} \mathrm{L}^{-1}$ (Sections 3.2 and 3.5). Oxygen depletion during this process hindered the further oxidation of DMS, DMDS, and DMTS to dimethyl sulfoxide [28,33], leading to the accumulation of DMS, DMDS, and DMTS in the water. Therefore, the concentrations of DMS, DMDS, and DMTS increased in July. In addition, the algae accumulation experiment in the laboratory also demonstrated that the concentrations of DMS, DMDS, and DMTS increased quickly with the depletion of oxygen after two days of the algae accumulation. These results indicate that the development of oxygen is crucial for the formation and development of VSCs in the water.

The development of oxygen not only influenced the formation and development of VSCs in the water, but also influenced the transformation of sulfur in the sediment. During the algae accumulation and decomposition, the depletion of oxygen in the water decreased the OPD across the 
SWI (Section 3.2), which facilitated the growth of sulfate-reducing bacteria and a reduction in sulfate in the sediment $[25,66]$. In addition, the deposition of the accumulated algae on the surface sediments increased the organic matter in the surface sediments, which further intensified the consumption of oxygen across the SWI $[67,68]$ and catalyzed the sulfate reduction. The oxygen depletion and sulfate reduction during the algae accumulation thereby increased the AVS concentrations in the surface sediments both during the field investigation (Section 3.3) and laboratory algae accumulation experiments (Section 3.5). The OPD was significantly negatively correlated $(p<0.01)$ to both the VSCs in the water and the AVS in the surface sediments (Figure 7, Table S3). While the VSCs originated from the decomposition of the accumulated algae in the water, the sulfides $\left(\mathrm{S}^{2-}\right)$ originated from the AVS in the sediment [22]. The high AVS in the surface sediments during the algae accumulation led to the release of sulfides $\left(\mathrm{S}^{2-}\right)$ and ferrous iron $\left(\mathrm{Fe}^{2+}\right)$ into the overlying water [40], leading to the black coloration of the water in Lake Taihu. Therefore, most of the algae-induced black coloration in Lake Taihu are likely to occur first at the bottom of the water column and then spread to the whole water column. The formation and development of these reductive sulfocompounds during the algae accumulation are the main causes of the black odorous events in Lake Taihu and of the drinking water crisis in 2007 [31,32]. In addition, the formation of reductive sulfides might accelerate the release of $\mathrm{P}$ from the sediments [14], which aggravates eutrophication and HABs in Lake Taihu. Therefore, the reduction in the accumulated algae amount in similar embay areas is crucial for the eutrophication management in Lake Taihu. The accumulated algae in these bays and littoral areas should be disposed timely through salvage or other measures to reduce further ecological disasters during the algae accumulation.

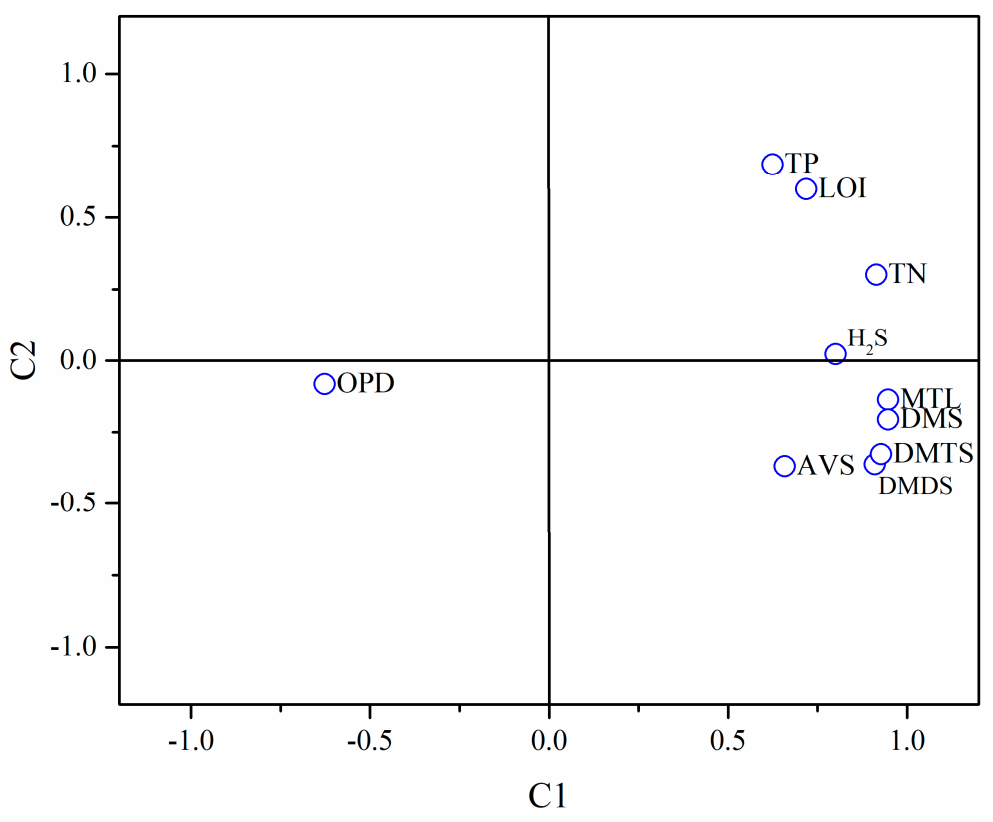

Figure 7. Principal component analysis $(\mathrm{C} 1, \mathrm{C} 2)$ of the various characteristics of water and sediments for the field investigation period. OPD: Oxygen penetration depth; TP: Total phosphorus in the sediment; LOI: Loss on ignition in the sediment; TN: Total nitrogen in the sediment; AVS: Acid volatile sulfide in the sediment; $\mathrm{H}_{2} \mathrm{~S}$ : Hydrogen sulfide in the water; MTL: Methanethiol in the water; DMS: Dimethyl sulfide in the water; DMDS: Dimethyl disulfide in the water; DMTS: Dimethyl trisulfide in the water.

\section{Conclusions}

Sulfur is crucial in a water-sediment system for the development of $\mathrm{P}$ and eutrophication. We observed the development of reductive sulfocompounds in the water-sediment system of the algae accumulation embay area in Lake Taihu. MTL and $\mathrm{H}_{2} \mathrm{~S}$ were the dominant VSCs in the water during January, April, and October, while significant increases in DMS, DMDS, and DMTS were observed in 
July with the serious algal bloom. The algae accumulation experiments in the laboratory also revealed an increase in DMS, DMDS, and DMTS. The depletion of oxygen during the algae accumulation and decomposition was found to be closely related to this phenomenon as well. In addition, the depletion of oxygen during the heavy algae accumulation increased the concentrations of AVS in the surface sediment, which thereby increased the risk of occurrence of the black coloration and an odor issue in the water-sediment system. The formation of large amounts of these reductive sulfocompounds in the water-sediment system might increase the release of $P$ from the sediments and aggravate eutrophication and the algal bloom. Therefore, the reduction of heavy algae accumulation in similar bay areas would be conducive to the eutrophication control in associated lakes.

Supplementary Materials: The following are available online at http://www.mdpi.com/2073-4441/11/9/1817/s1, Table S1. Introduction of the analysis of covariance (ANCOVA) during the statistical analysis. Table S2. Sediment properties and variations during the field investigation. Table S3. Pearson's correlation matrix of various characteristics.

Author Contributions: Conceptualization, C.L.; Investigation, C.L., S.S., and L.Z.; Project administration, Y.Y.; Supervision, C.F.; Writing—original draft preparation, C.L.; Writing—review and editing, Y.D. and K.C.

Funding: This study was supported by the National Natural Science Foundation of China (No. 41703078), the Natural Science Foundation of Jiangsu Province (No. BK20171101 and BK20161613), and the State Major Project for Water Pollution Control and Management (No. 2018ZX07208-004).

Conflicts of Interest: The authors declare no conflict of interest.

\section{References}

1. Müller, S.; Mitrovic, S.M. Phytoplankton co-limitation by nitrogen and phosphorus in a shallow reservoir: Progressing from the phosphorus limitation paradigm. Hydrobiologia 2015, 744, 255-269. [CrossRef]

2. Conley, D.J.; Paerl, H.W.; Howarth, R.W.; Boesch, D.F.; Seitzinger, S.P.; Havens, K.E.; Lancelot, C.; Likens, G.E. Controlling eutrophication: Nitrogen and phosphorus. Science 2009, 323, 1014-1015. [CrossRef] [PubMed]

3. Fennel, K.; Testa, J.M. Biogeochemical Controls on Coastal Hypoxia. Ann. Rev. Mar. Sci. 2019, 11, 105-130. [CrossRef] [PubMed]

4. Landsberg, J.H. The effects of harmful algal blooms on aquatic organisms. Rev. Fish. Sci. 2002, 10, 113-390. [CrossRef]

5. Sayer, C.D.; Burgess, A.; Kari, K.; Davidson, T.A.; Peglar, S.; Yang, H.; Rose, N. Long-term dynamics of submerged macrophytes and algae in a small and shallow, eutrophic lake: Implications for the stability of macrophyte-dominance. Freshw. Biol. 2010, 55, 565-583. [CrossRef]

6. Murphy, F.; Schmieder, K.; Baastrup-Spohr, L.; Pedersen, O.; Sand-Jensen, K. Five decades of dramatic changes in submerged vegetation in Lake Constance. Aquat. Bot. 2018, 144, 31-37. [CrossRef]

7. Irfanullah, H.M.; Moss, B. Factors influencing the return of submerged plants to a clear-water, shallow temperate lake. Aquat. Bot. 2004, 80, 177-191. [CrossRef]

8. Cattaneo, A.; Galanti, G.; Gentinetta, S.; Romo, S. Epiphytic algae and macroinvertebrates on submerged and floating-leaved macrophytes in an Italian lake. Freshw. Biol. 1998, 39, 725-740. [CrossRef]

9. Brothers, S.M.; Hilt, S.; Attermeyer, K.; Grossart, H.P.; Kosten, S.; Lischke, B.; Mehner, T.; Meyer, N.; Scharnweber, K.; Köhler, J. A regime shift from macrophyte to phytoplankton dominance enhances carbon burial in a shallow, eutrophic lake. Ecosphere 2013, 4,1-17. [CrossRef]

10. Scheffer, M.; van Nes, E.H. Shallow lakes theory revisited: Various alternative regimes driven by climate, nutrients, depth and lake size. Hydrobiologia 2007, 584, 455-466. [CrossRef]

11. Randall, M.C.; Carling, G.T.; Dastrup, D.B.; Miller, T.; Nelson, S.T.; Rey, K.A.; Hansen, N.C.; Bickmore, B.R.; Aanderud, Z.T. Sediment potentially controls in-lake phosphorus cycling and harmful cyanobacteria in shallow, eutrophic Utah Lake. PLoS ONE 2019, 14, e0212238. [CrossRef] [PubMed]

12. Gunnars, A.; Blomqvist, S. Phosphate exchange across the sediment-water interface when shifting from anoxic to oxic conditions an experimental comparison of freshwater and brackish-marine systems. Biogeochemistry 1997, 37, 203-226. [CrossRef] 
13. Rozan, T.F.; Taillefert, M.; Trouwborst, R.E.; Glazer, B.T.; Ma, S.; Herszage, J.; Valdes, L.M.; Price, K.S.; Luther, G.W., III. Iron-sulfur-phosphorus cycling in the sediments of a shallow coastal bay: Implications for sediment nutrient release and benthic macroalgal blooms. Limnol. Oceanogr. 2002, 47, 1346-1354. [CrossRef]

14. Wu, S.; Zhao, Y.; Chen, Y.; Dong, X.; Wang, M.; Wang, G. Sulfur cycling in freshwater sediments: A cryptic driving force of iron deposition and phosphorus mobilization. Sci. Total Environ. 2019, 657, 1294-1303. [CrossRef] [PubMed]

15. Geurts, J.J.M.; Sarneel, J.M.; Willers, B.J.C.; Roelofs, J.G.M.; Verhoeven, J.T.A.; Lamers, L.P.M. Interacting effects of sulphate pollution, sulphide toxicity and eutrophication on vegetation development in fens: A mesocosm experiment. Environ. Pollut. 2009, 157, 2072-2081. [CrossRef] [PubMed]

16. Me, V.D.W.; Cuppens, M.; Lamers, L.P.; Roelofs, J.G. Detoxifying toxicants: Interactions between sulfide and iron toxicity in freshwater wetlands. Environ. Toxicol. Chem. 2006, 25, 1592-1597.

17. Caraco, N.; Cole, J.; Likens, G. Evidence for sulphate-controlled phosphorus release from sediments of aquatic systems. Nature 1989, 341, 316-318. [CrossRef]

18. Howarth, R.W.; Marino, R. Nitrogen as the limiting nutrient for eutrophication in coastal marine ecosystems: Evolving views over three decades. Limnol. Oceanogr. 2006, 51, 364-376. [CrossRef]

19. Schindler, D.W.; Carpenter, S.R.; Chapra, S.C.; Hecky, R.E.; Orihel, D.M. Reducing phosphorus to curb lake eutrophication is a success. Environ. Sci. Technol. 2016, 50, 8923-8929. [CrossRef]

20. Søndergaard, M.; Jensen, J.P.; Jeppesen, E. Role of sediment and internal loading of phosphorus in shallow lakes. Hydrobiologia 2003, 506, 135-145. [CrossRef]

21. Hupfer, M.; Lewandowski, J. Oxygen Controls the Phosphorus Release from Lake Sediments-A Long-Lasting Paradigm in Limnology. Int. Rev. Hydrobiol. 2008, 93, 415-432. [CrossRef]

22. Liu, C.; Shen, Q.; Zhou, Q.; Fan, C.; Shao, S. Precontrol of algae-induced black blooms through sediment dredging at appropriate depth in a typical eutrophic shallow lake. Ecol. Eng. 2015, 77, 139-145. [CrossRef]

23. Shen, Q.; Liu, C.; Zhou, Q.; Shang, J.; Zhang, L.; Fan, C. Effects of physical and chemical characteristics of surface sediments in the formation of shallow lake algae-induced black bloom. J. Environ. Sci. 2013, 25, 2353-2360. [CrossRef]

24. Molot, L.; Watson, S.; Creed, I.; Trick, C.; McCabe, S.; Verschoor, M.; Sorichetti, R.; Powe, C.; Venkiteswaran, J.; Schiff, S. A novel model for cyanobacteria bloom formation: The critical role of anoxia and ferrous iron. Freshw. Biol. 2014, 59, 1323-1340. [CrossRef]

25. Feng, Z.; Fan, C.; Huang, W.; Ding, S. Microorganisms and typical organic matter responsible for lacustrine "black bloom". Sci. Total Environ. 2014, 470, 1-8. [CrossRef] [PubMed]

26. Ginzburg, B.; Chalifa, I.; Gun, J.; Dor, I.; Hadas, O.; Lev, O. DMS formation by dimethylsulfoniopropionate route in freshwater. Environ. Sci. Technol. 1998, 32, 2130-2136. [CrossRef]

27. Lu, X.; Fan, C.X.; He, W.; Deng, J.C.; Yin, H.B. Sulfur-containing amino acid methionine as the precursor of volatile organic sulfur compounds in algea-induced black bloom. J. Environ. Sci. China 2013, 25, 33-43. [CrossRef]

28. Bentley, R.; Chasteen, T.G. Environmental VOSCs--Formation and degradation of dimethyl sulfide, methanethiol and related materials. Chemosphere 2004, 55, 291-317. [CrossRef] [PubMed]

29. Lee, J.; Rai, P.K.; Jeon, Y.J.; Kim, K.H.; Kwon, E.E. The role of algae and cyanobacteria in the production and release of odorants in water. Environ. Pollut. 2017, 227, 252-262. [CrossRef]

30. Song, C.; Liu, X.; Song, Y.; Liu, R.; Gao, H.; Han, L.; Peng, J. Key blackening and stinking pollutants in Dongsha River of Beijing: Spatial distribution and source identification. J. Environ. Manag. 2017, 200, 335-346. [CrossRef]

31. Yang, M.; Yu, J.; Li, Z.; Guo, Z.; Burch, M.; Lin, T. Taihu Lake not to blame for Wuxi's woes. Science 2008, 319, 158. [CrossRef] [PubMed]

32. Zhang, X.J.; Chen, C.; Ding, J.Q.; Hou, A.X.; Li, Y.; Niu, Z.B.; Su, X.Y.; Xu, Y.J.; Laws, E.A. The 2007 water crisis in Wuxi, China: Analysis of the origin. J. Hazard. Mater. 2010, 182, 130-135. [CrossRef] [PubMed]

33. Hwang, Y.; Matsuo, T.; Hanaki, K.; Suzuki, N. Removal of odorous compounds in wastewater by using activated carbon, ozonation and aerated biofilter. Water Res. 1994, 28, 2309-2319. [CrossRef]

34. Lomans, B.; Van der Drift, C.; Pol, A.; den Camp, H.O. Microbial cycling of volatile organic sulfur compounds. Cell. Mol. Life Sci. 2002, 59, 575-588. [CrossRef] 
35. Xu, S.; Huang, B.; Wei, Z.B.; Luo, J.; Miao, A.J.; Yang, L.Y. Seasonal variation of phytoplankton nutrient limitation in Lake Taihu, China: A monthly study from Year 2011 to 2012. Ecotoxicol. Environ. Saf. 2013, 94, 190-196. [CrossRef]

36. Jones, G.J.; Bourne, D.G.; Blakeley, R.L.; Doelle, H. Degradation of the cyanobacterial hepatotoxin microcystin by aquatic bacteria. Nat. Toxins 1994, 2, 228-235. [CrossRef] [PubMed]

37. Qin, B.; Xu, P.; Wu, Q.; Luo, L.; Zhang, Y. Environmental issues of lake Taihu, China. Hydrobiologia 2007, 581, 3-14. [CrossRef]

38. Duan, H.; Loiselle, S.A.; Zhu, L.; Feng, L.; Zhang, Y.; Ma, R. Distribution and incidence of algal blooms in Lake Taihu. Aquat. Sci. 2015, 77, 9-16. [CrossRef]

39. Wu, T.; Qin, B.; Ding, W.; Zhu, G.; Zhang, Y.; Gao, G.; Xu, H.; Li, W.; Dong, B.; Luo, L. Field observation of different wind-induced basin-scale current field dynamics in a large, polymictic, eutrophic lake. J. Geophys. Res. Ocean. 2018, 123, 6945-6961. [CrossRef]

40. Shen, Q.; Fan, C.; Liu, C.; Chen, C. The limiting factor to the outbreak of lake black bloom: Roles of ferrous iron and sulfide ions. CLEAN Soil Air Water 2018, 46, 1800305. [CrossRef]

41. Chen, J.; Xie, P.; Ma, Z.; Niu, Y.; Tao, M.; Deng, X.; Wang, Q. A systematic study on spatial and seasonal patterns of eight taste and odor compounds with relation to various biotic and abiotic parameters in Gonghu Bay of Lake Taihu, China. Sci. Total Environ. 2010, 409, 314-325. [CrossRef] [PubMed]

42. Liu, G.; Shen, Q.; Zhang, L.; Fan, C.; Zhong, J.; Yan, S. Environment effects of algae-caused black spots: Driving effects on the N, P changes in the water-sediment interface. Environ. Sci. 2010, 31, 2917-2924.

43. Shang, L.; Ke, F.; Li, W.; Xu, X.; Song, Y.; Feng, M. Laboratory research on the contaminants release during the anaerobic decomposition of high-density cyanobacteria. J. Lake Sci. 2013, 25, 47-54.

44. Allen, H.E.; Fu, G.; Boothman, W.; Di Toro, D.; Mahony, J. Determination of Acid Volatile Sulfide and Selected Simultaneously Extractable Metals in Sediment; Office of Water Regulations and Standards, US Environmental Protection Agency: Washington, DC, USA, 1991; p. 18.

45. Cline, J.D. Spectrophotometric determination of hydrogen sulfide in natural waters. Limnol. Oceanogr. 1969, 14, 454-458. [CrossRef]

46. Rasmussen, H.; Jorgensen, B.B. Microelectrode studies on seasonal oxygen uptake in a coastal sediment: Role of molecular diffusion. Mar. Ecol. Prog. 1992, 81, 289-303. [CrossRef]

47. Boudreau, B.P. The diffusive tortuosity of fine-grained unlithified sediments. Geochim. Cosmochim. Acta 1996, 60, 3139-3142. [CrossRef]

48. Cermelj, B.; Bertuzzi, A.; Faganeli, J. Modelling of pore water nutrient distribution and benthic fluxes in shallow coastal waters (Gulf of Trieste, Northern Adriatic). Water Air Soil Pollut. 1997, 99, 435-443. [CrossRef]

49. Chinese-EPA. Methods for the Examination of Water and Wastewater, 4th ed.; China Environmental Science Press: Beijing, China, 2002.

50. Ruban, V.; López-Sánchez, J.; Pardo, P.; Rauret, G.; Muntau, H.; Quevauviller, P. Selection and evaluation of sequential extraction procedures for the determination of phosphorus forms in lake sediment. J. Environ. Monit. 1999, 1, 51-56. [CrossRef] [PubMed]

51. Dean, W.E. Determination of carbonate and organic matter in calcareous sediments and sedimentary rocks by loss on ignition; comparison with other methods. J. Sediment. Res. 1974, 44, 242-248.

52. Liu, C.; Shao, S.; Shen, Q.; Fan, C.; Zhou, Q.; Yin, H.; Xu, F. Use of multi-objective dredging for remediation of contaminated sediments: A case study of a typical heavily polluted confluence area in China. Environ. Sci. Pollut. Res. 2015, 22, 17839-17849. [CrossRef]

53. Liu, C.; Du, Y.; Yin, H.; Fan, C.; Chen, K.; Zhong, J.; Gu, X. Exchanges of nitrogen and phosphorus across the sediment-water interface influenced by the external suspended particulate matter and the residual matter after dredging. Environ. Pollut. 2019, 246, 207-216. [CrossRef] [PubMed]

54. Akomeah, E.; Lindenschmidt, K.E. Seasonal Variation in Sediment Oxygen Demand in a Northern Chained River-Lake System. Water 2017, 9, 254. [CrossRef]

55. Thode-Andersen, S.; Jørgensen, B.B. Sulfate reduction and the formation of 35S-labeled FeS, FeS2, and S0 in coastal marine sediments. Limnol. Oceanogr. 1989, 34, 793-806. [CrossRef]

56. Marschall, C.; Frenzel, P.; Cypionka, H. Influence of oxygen on sulfate reduction and growth of sulfatereducing bacteria. Arch. Microbiol. 1993, 159, 168-173. [CrossRef]

57. Jørgensen, B.B. The sulfur cycle of a coastal marine sediment (Limfjorden, Denmark). Limnol. Oceanogr. 1977, 22, 814-832. [CrossRef] 
58. Liu, C.; Shao, S.; Shen, Q.; Fan, C.; Zhang, L.; Zhou, Q. Effects of riverine suspended particulate matter on the post-dredging increase in internal phosphorus loading across the sediment-water interface. Environ. Pollut. 2016, 211, 165-172. [CrossRef] [PubMed]

59. Duval, B.; Ludlam, S.D. The black water chemocline of meromictic Lower Mystic Lake, Massachusetts, USA. Int. Rev. Hydrobiol. 2001, 86, 165-181. [CrossRef]

60. Lu, G.H.; Ma, Q. Analysis on the causes of forming black water cluster in Taihu Lake. Adv. Water Sci. 2009, 20, 438-442.

61. Watson, S.B. Aquatic taste and odor: A primary signal of drinking-water integrity. J. Toxicol. Environ. Health Part Curr. Issues 2004, 67, 1779-1795. [CrossRef]

62. Higgins, M.J.; Chen, Y.C.; Yarosz, D.P.; Murthy, S.N.; Maas, N.A.; Glindemann, D.; Novak, J.T. Cycling of volatile organic sulfur compounds in anaerobically digested biosolids and its implications for odors. Water Environ. Res. 2006, 78, 243-252. [CrossRef]

63. Lomans, B.; Pol, A.; den Camp, H.O. Microbial cycling of volatile organic sulfur compounds in anoxic environments. Water Sci. Technol. 2002, 45, 55-60. [CrossRef] [PubMed]

64. Chin, H.W.; Lindsay, R.C. Ascorbate and transition-metal mediation of methanethiol oxidation to dimethyl disulfide and dimethyl trisulfide. Food Chem. 1994, 49, 387-392. [CrossRef]

65. Li, K. The Feasibility Study on the Use of Cyanobacteria of Taihu Lake. Master's Thesis, Jiangnan University, Wuxi, China, 2009.

66. Freitag, T.E.; Klenke, T.; Krumbein, W.E.; Gerdes, G.; Prosser, J.I. Effect of anoxia and high sulphide concentrations on heterotrophic microbial communities in reduced surface sediments (Black Spots) in sandy intertidal flats of the German Wadden Sea. FEMS Microbiol. Ecol. 2003, 44, 291-301. [CrossRef]

67. Hulthe, G.; Hulth, S.; Hall, P.O. Effect of oxygen on degradation rate of refractory and labile organic matter in continental margin sediments. Geochim. Cosmochim. Acta 1998, 62, 1319-1328. [CrossRef]

68. Kristensen, E. Organic matter diagenesis at the oxic/anoxic interface in coastal marine sediments, with emphasis on the role of burrowing animals. Hydrobiologia 2000, 426, 1-24. [CrossRef]

(C) 2019 by the authors. Licensee MDPI, Basel, Switzerland. This article is an open access article distributed under the terms and conditions of the Creative Commons Attribution (CC BY) license (http://creativecommons.org/licenses/by/4.0/). 